\title{
EXTRAORDINARY LANDSCAPES \\ FOLLOWING THE ERA \\ OF THE INDUSTRY
}

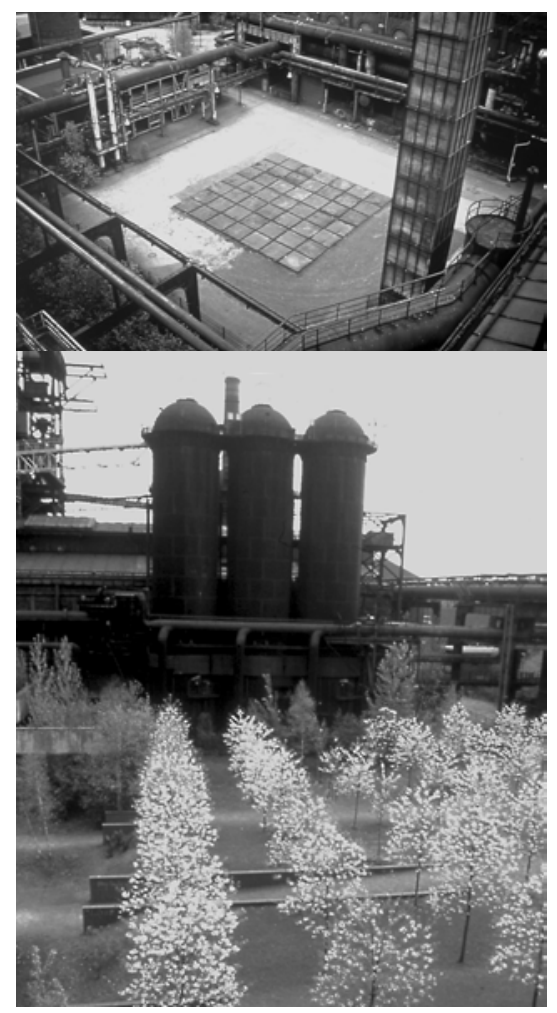

Peter Latz

Technical University of Munich.

Projeto 


\section{RESUMO}

Com cerca de 100 projetos, o "Internacional Building Exibition Center Park" (IBA), no distrito do Ruhr, na Alemanha, focou-se em estabelecer padrões construtivos de qualidade e de planejamento para as transformações ambientais, econômicas e sociais desta antiga área industrial. $\bigcirc$ parque paisagístico Duisburg Nord, apresentado neste artigo, é um destes projetos.

A idéia foi de integrar forma, desenvolvimento e interligar as estruturas ainda existentes, formadas pelo uso industrial até então vigente, e encontrar uma nova interpretação com uma nova sintaxe e os fragmentos em questão foram interligados por um novo paisagismo.

O objetivo final não foi evocar um todo, as estruturas construídas, que aparecem como planos independentes que são interligadas visualmente, ou funcionalmente ou somente pela imaginação. Tem-se que:

- o parque ferroviário com promenades e passarelas de pedestres no nível mais alto; o parque/aquático no nível mais baixo, apresentando um sistema ecológico especial; os campos de vegetação entre as estruturas ferroviárias e o parque aquático; o parque de fumaça com plataformas de observação, jardins de rochas, áreas de escalada, etc.; o sinterpark com sua área para festivais; a promenade no nível das ruas, conectando partes da cidade antes separadas e pequenos parques e jardins de transição para as áreas residenciais.

É apontada ainda a existência de outros projetos que adotam estas posturas de aproveitamento do contexto histórico preexistente.

\section{ABSTRACT}

With some 100 projects, the International Building Exhibition Emscher Park (IBA) in the Ruhr District of Germany attempted to set quality building and planning standards for the environmental, economic and social transformation of this old industrialized region. The landscape park Duisburg Nord is one of these projects. The idea was to integrate, shape, develop and interlink the existing patterns that were formed by its previous industrial use, and to find a new interpretation with a new syntax. The existing fragments were to be interlaced into a new "landscape". Technical constructions of engineering become the most perfect landscape elements and symbols, they create new references by adaptation, they become "land art". The aim is not the often invoked "entirety". The characteristic structures are not changed or alienated, but appear as independent layers that are linked together either visually, functionally or only imaginary:

The railway park with its promenades and footbridges at the highest level; the waterpark with a now ecological rain water system at the lowest level; the single fields of vegetation between the ribbonlike structures of the railway - and the waterpark, the blast furnace park with observation platforms, catwalks, places, climbing - and rockgardens; the Sinterpark with its large festival ground; the promenades on street level, connecting formerly separated parts of the town, and separate little parks and gardens in transition to the neighbouring housing areas. There are others projects that adopt these position to make good use of preexistent historical context. 


\section{EXTRAORDINARY LANDSCAPES FOLLOWING THE ERA OF THE INDUSTRY}

Figura 1 - Smoke and dust in the air of Duisburg Fonte: Latz + Partner

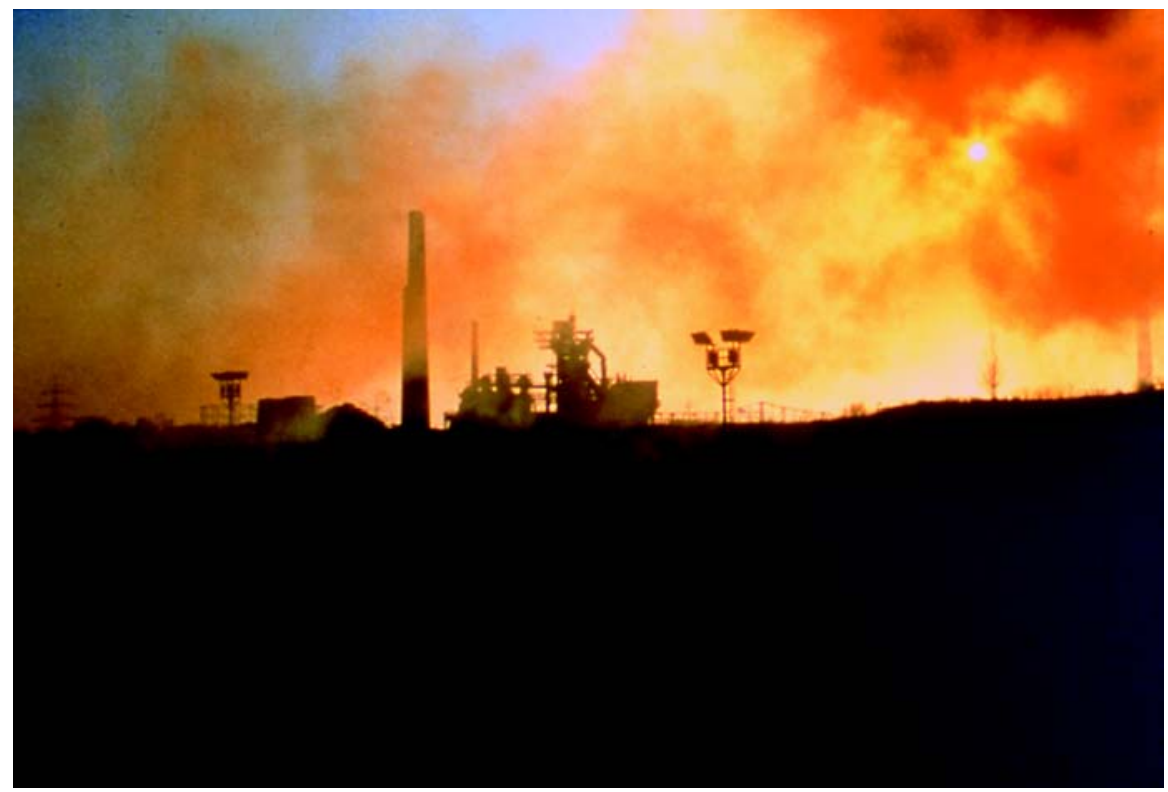

Ladies and Gentlemen,

A new type of landscape is forming in all developed countries, having nothing in common neither with natural, agricultural nor with the literary landscapes.

To define these areas as "damages of the landscape" and to claim their recultivation like an agricultural land, does not do justice to them.

For the present we call them the fantastic landscapes following the era of the industry - a type of landscape we have to deal with in a new and careful way.

To begin with I would like to touch on the IBA program.

You see here the map in Germany and in the north western plain the Emscher district east of the river Rhine.

The northern Ruhr area the coal, iron and steel industries, shrunken by periodical crises, have left behind a bizarre landscape: spaces torn to pieces, environmental damages, land settlements with swamps and polders, slag-heaps where 
floodplain forests were growing, and soils, polluted with polyaromatic hydrocarbons and heavy metal.

The fundamental ecological bases of the landscape have to be restored again, to make this area with two and a half $(2,5)$ million inhabitants attractive again for new investments.

This was and still is the aim of the International Building Exhibition Emscher Park (IBA), and of its president professor Karl Ganser - you see him on the right picture.

It was agreed already in the twenties, to create green connections from north to south. Only some of them were realized.

Emscher Park - that means now the green connections with landscape elements from east to west.

- "70 kilometers hope" - (as Manfred Sac, on of our most renowned journalists, calls his book about the IBA Emscher Park).

It means:

- ecological reclamation;

- new work - in Duisburg in the old buildings;

- social initiatives;

- new housing developments and renewing of old worker's settlements (here the estate "Teutoburgia");

- the connection of industrial heritage and tourism;

- and the landmarks - here the blast furnaces with the illumination of Jonathan Park, as they are used as signet;

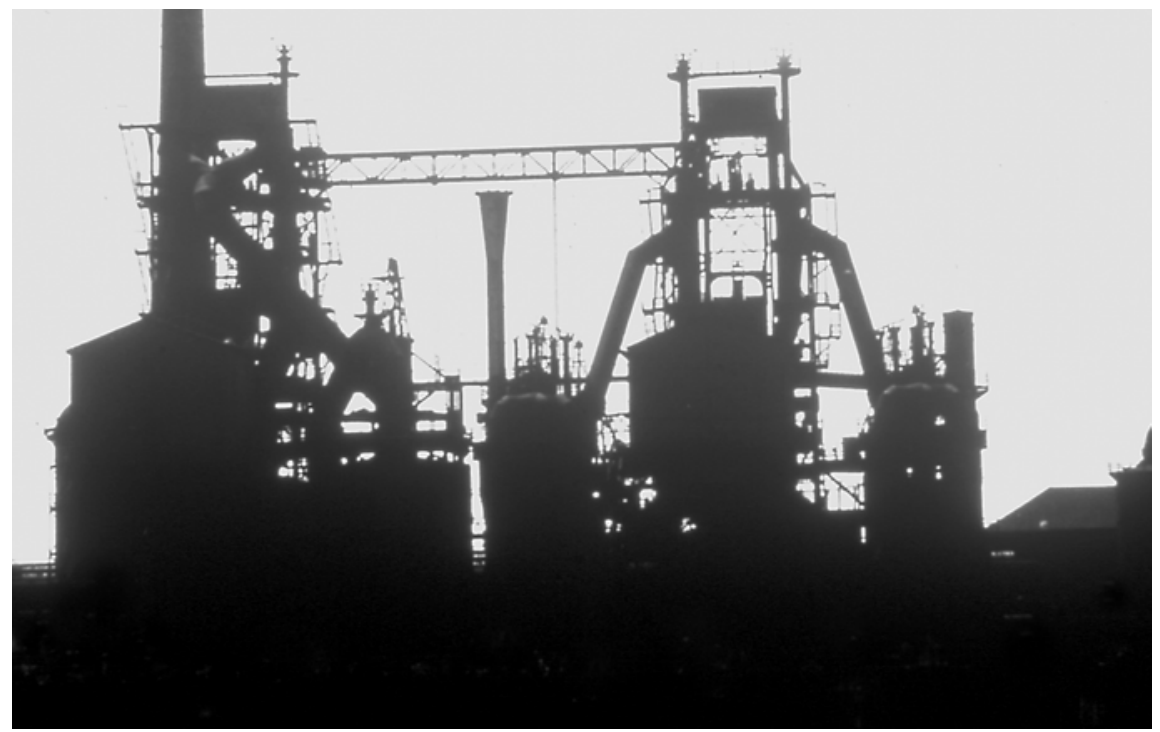

Figura 2 - The silhovette of the blast furnace Fonte: Latz + Partner 
The Piazza Metallica is the symbol of the park and at the same time program of my work, the metamorphosis of the existing hard industrial structure into a public park.

The park itself reflects the discussion of new ideas about landscape and nature.

The original idea for this artefact amidst the blast furnace plan was, to represent the process of iron, manufactured in both its molten and hardened states.

Melting and hardening was to be simulated by water, flowing and settling on various surfaces.

We found iron plates in the - at this time still productive - pig-iron casting works. These plates were used to cover casting moulds.

The process caused the plates to take on individual forms of erosion.

We took the most interesting plates and arranged them in the middle of our selected space.

Cleaned of ashes and of casting sediments, the plates revealed their subtle patterns.

Ice and iron - a shimmering square at rainfall.

"Physical nature" becomes a symbolic theme. From the first moments of their existence, these plates are eroded by natural physical processes and will continue to rust and erode.

There is a persistent discussion about the question of utilization. Our position is and has always been: instead of building objects for specific uses, fantasy should allow to use the existing abstract structures in new ways - to deal with them and to play with them.

Figura 3 - The Piazza Metallica Fonte: Michael Latz

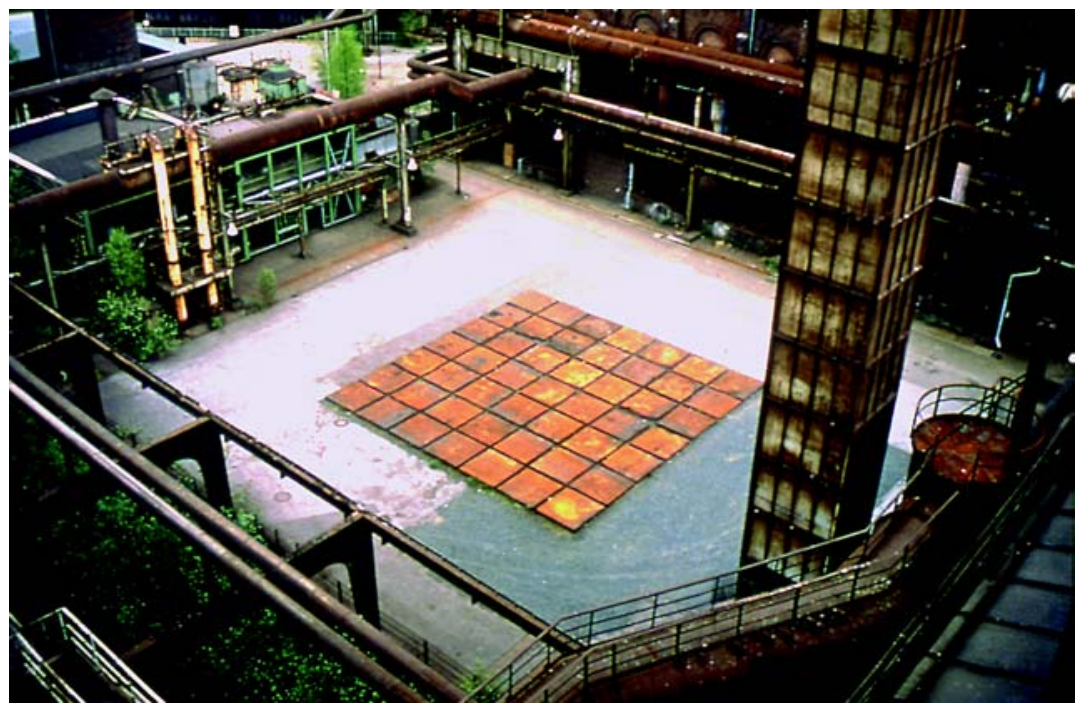


Thus our working method is one of adaptation and new interpretation, a metamorphosis of industrial structures without destroying them: the blast furnace is not only an old furnace - it is a menacing dragon ahead of frightened men, and it is also a mountain, used by climbers and rising above its surrounding.

Here, the former are bunkers become the rock faces of a mountain scenery, there they are enclosed gardens.

Already for some time, the huge are bunker walls have been used for climbing. The cracks and scars, formed by the ore ripping into the surfaces of the concrete, have allowed free climbers to practice their sport.

For the younger mountaineers, there is an "ascent to the alpine pasture" - a mountain slope with a huge slide, sandboxes and climbing net.

Interesting is another use: A diving club has established itself in the deep "caves", where ground water has formed underground lakes. The divers remove impurities and rubbish, and search for adventure in underground corridors.

The newest success is a diving centre in the old gasometer: it was floated to the brim with twenty-five-thousand (25.000) cubic metres of water.

In future, also diving classes and public events are to be held in this submarine world.

The fear of pollution and contamination has given way to a calm acceptance of the structures.

The so - called Cowper Place was initially controversial because of its location within the blast furnace plant.

Nobody believed in celebrating there in reality - with blossoming trees, "locked up in iron" in the beginning, weaving into the framework of the pipes of the windheaters and of the blast furnaces.

In spite of their size, the blast furnace plant, the Cowper Place, the water channel in the north and the picturesque harp of rails - I will talk about this in a minute - are interventions only within a small section of the park.

This zone includes a lot of buildings and architectural structures.

As an industrial heritage, they are available now for the other purposes.

Five architects and about twelve engineers were involved in the renewal of the old buildings: here the huge hall of the former central power station. A lot of events has taken place there already.

You can see the chaos of the agglomeration of the different settlements and infrastructure lines on the aerial view.

The two hundred (200) hectares site largely consists of parts, that are left to develop on their own without intensive treatment, or of heavily contaminated parts, that have to remain under guard. 
Figura 4 - The

Cowper Place

Fonte: Christa

Panick

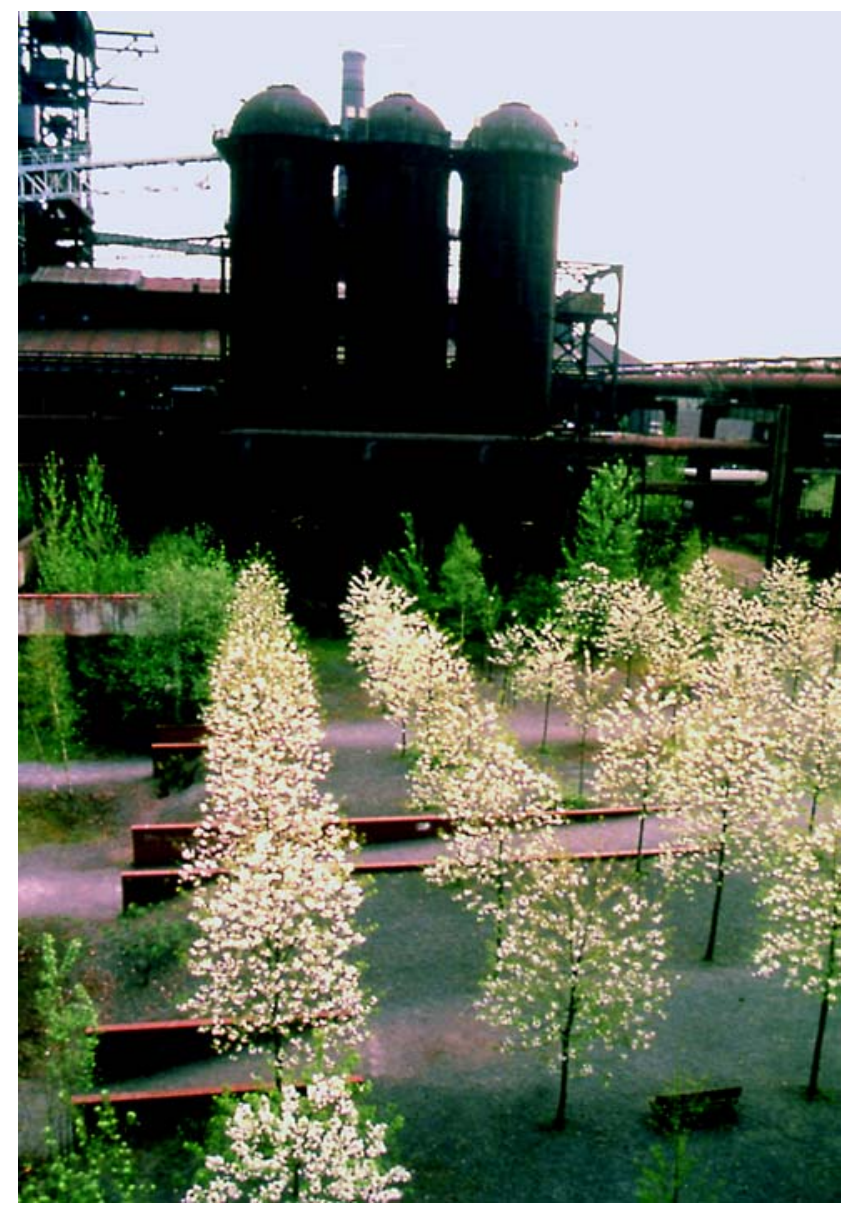

Figura 5 -

Concept plan of layers ans linking elements

Fonte: Latz + Partner

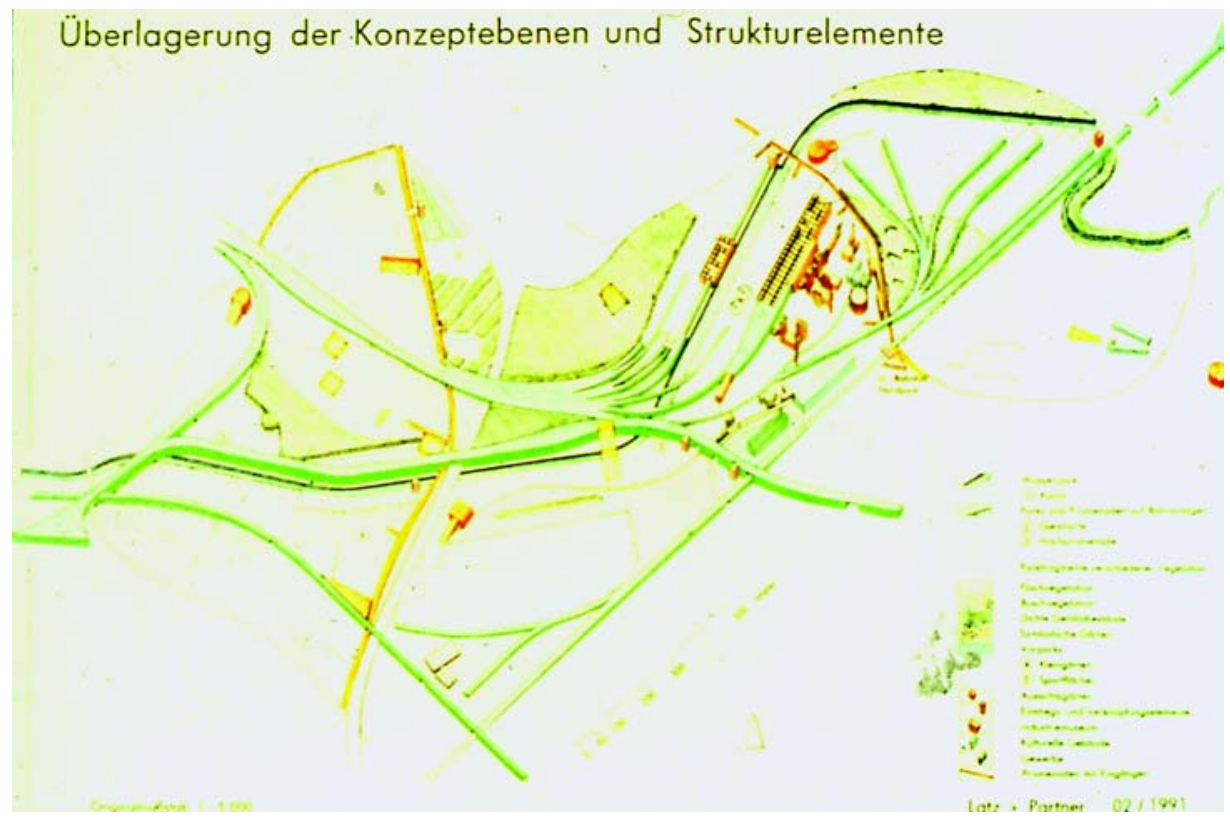


Certain principles were adopted for the park and are revealed in the overall design. There are individual systems, operating independently. These layers connect only at certain points through linking elements.

The uppermost layer is the railway park with its high level promenades, and the lowest layer is the deep-set water park.

Other individual systems are the connecting promenades at street level, and the single fields and clumps of vegetation.

The railway park is now developed.

High dams cross the landscape, wherever they were needed for production. Reaching a height of up to twelve (12) metres, these berms are higher than any of the natural terrain, and so offer views, which were never possible before.

They consist of slogs of high $\mathrm{pH}$-value, that are able to immobilize heavy metals. Therefore, the usable surfaces are covered with chips, made of dolomitic limestone, also with high $\mathrm{pH}$-value.

The most interesting area of the par, already worked out by vegetation management, is the "rail harp" - a bundle of rails, in which each rail leads to both a lower and an upper level. This was created by the collective work of engineers, slowly evolving over the hundreds years' history of the place.

112 Now, a huge land art has developed, slowly elaborated again by gardeners. It can be interpreted only now, since only now can it be viewed and comprehended.

The second system - the "water park" - is almost finished. Only some minor sections are still under construction.

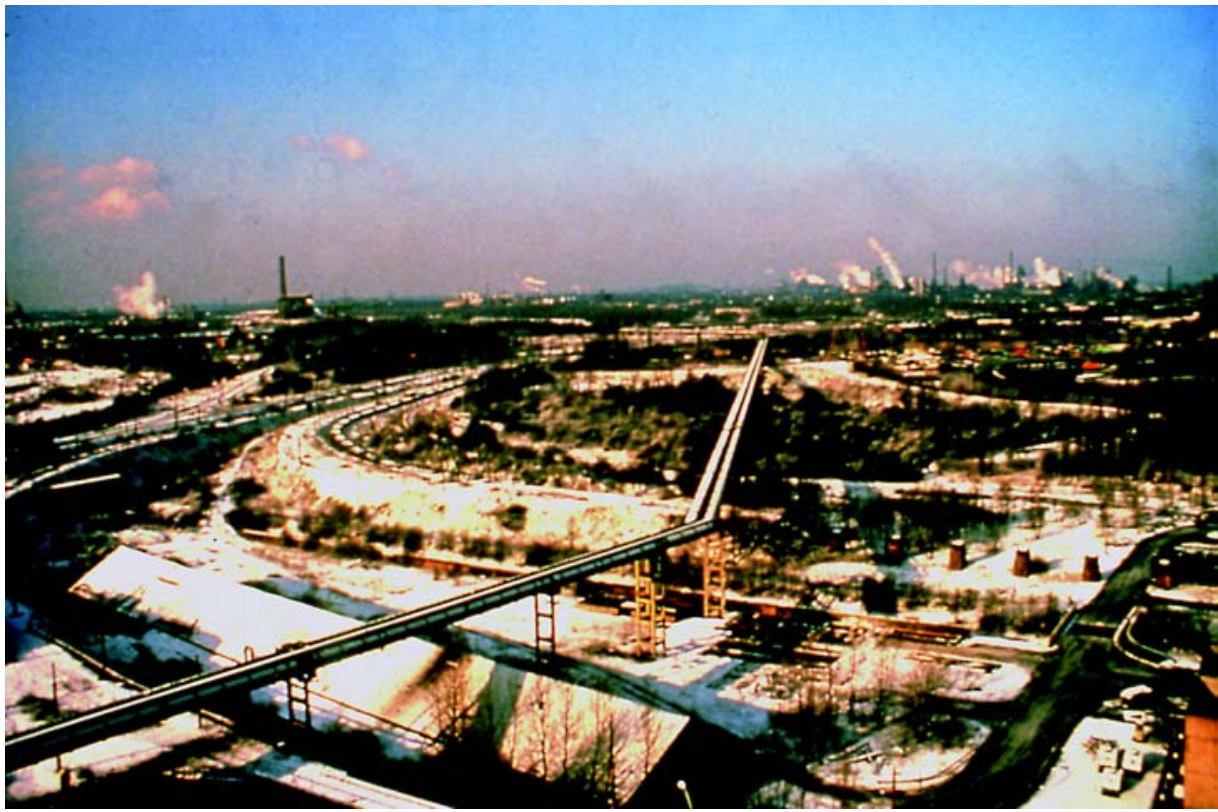

Figura 6 - The arp of rails (winter) Fonte: Latz + Partner 
Natural water no longer exists on the site, due also to the extensive sealing of large areas. The fist zone of saturation is contaminated by polyaromatic hydrocarbons.

The open waste water ditch of the "Old Emscher" crossing the park from east to west, was carrying non-treated sewage to the river Rhine.

Except for the crossing of a slaghill, we wanted to use the profile of this old construction, to avoid contact with the polluted ground of the surroundings.

Within this profile a new cleans water system is installed.

Water had to be collected from the buildings and the surfaces of the site, and then to be led to the new canal though open drains and ditches.

The waste water is carried within a 3,5 meters diameter underground main.

It is sealed by a layer of clay, which collects run off from the buildings, bunkers and cooling basins.

Two "water paths" are working effectively: rainwater flows in open rivulets - and through the existing overhead pipe systems. It flows also through new pipes, here at the old powerstation, collecting rainwater from a roof of about six-thousand five hundred (6.500) square meters.

It falls into the former cooling basins, thus becoming enriched by oxygen.

Now, waterlilies and iris bloom in pure water, and fish and dragonflies live in a nex biotope.

Former settling tanks have been cleaned of five hundred (500) tons of arsenic mud, and are now supplied with clean clear water, pumped from the depth of the old are bunkers.

The arsenic mud was squeezed out and loaded into old mines.

Meanwhile, the bed of the new Old Emscher is filled.

The system of the waterpaths leads through the whole blast furnace site - open and visible - into the direction of the new canal and the collecting rivulets flow into the clean clear watercourse.

Platforms with seats are waiting for visitors and little islands will be colonized by flora and fauna.

A most spectacular installation was set up in the tower of the former sintering plant.

We had the idea of using the power of the wind for an oxygenation system.

Before the setting up of the windwheel, the old construction had to be stabilized. 
The huge windwheel is the worldwide biggest multifoliate rotor ever made with sixteen (16) meters diameters.

It is exactly the type of windwheel, that the firm has produced in the last century for the farmers in America. You will recognize it in every western film.

Water is pumped from the canal through an archimedean spiral, and falls from several points after a journey through the gardens.

This enriches the biological system with oxygen, as well as being an attraction to visitors.

The water channel is an artefact aiming at natural processes in as devastated and perverted situation. They follow ecological rules, but are initiated and maintained by technological processes.

Man uses this artefact as a symbol for nature, but remains responsible for the process.

It is the most natural and at the same time the most artificial system.

Another fascinating layer in the park is a crazy looking vegetation. Already in February, a dazzling yellow covers the railway areas, and lichens and mosses 114 grow on the stones of the slag heaps.

These area contaminated ashes - they are not accessible, therefore they can remain. The preservation of this special situation was more important for us than a decontamination, that would have covered the place completely.

You can see here the plan of the site with its more than two hundred hectares. The vegetation does not cover the park evenly, or as it might in "natural" landscapes.

Instead, "vegetation fields" lie like single different clumps between the ribbonlike structures of the railway and the water park, covering isolate areas with differentiated forms and colours.

Briches for example, are now colonizing the black waste material of the coal washing process.

This coal-mine spoil covers the former coking plant, that is heavily contaminated with polyaromatic hydrocarbons (PAH).

There are two alternatives to deal with this problem:

1. Layers of clay and the total loss of vegetation - an "eternal" grave of historical burdens or; 
2. to have slight gas diffusion over the course of several generation, with a corresponding reduction of contamination and limited utilization, such as only cycling, walking, etc.

In Duisburg we preferred the second solution.

Exactly in this part of the park the Ruhr-Mining Company hat started the other program:

At the same time when we worked on the project, they started to cover the site with layers of clay and soil, $1 \mathrm{~m}$ thick, and to destroy the situation - to cover the pollution and to make a pseudo-natural landscape. Only the IBA had the power to prevent this and to follow our conception.

Steppe-like vegetation grows on the meagre soil of coal-soot mixes.

It grows on casting sediments and slags of the recently shut down manganese ore depot and manganese foundry.

So these are independent vegetation fragments, but within the Ruhr area repeatedly returning typologies, with lots of species immigrated from over the world, called neophytes. This made it necessary, to train gardeners especially for their management and care.

Another part of the park is the site of the former sintering plant.

The transformation of this site represents another form of metamorphosis that of recycling.

Due to heavy contamination, the plant had to be almost completely demolished.

The contaminated material was filled into the sealed bags of the sinter bunkers and covered with "roof gardens".

Stones, which were not contaminated, were ground down, to become new soil, new stones, surfaces and also concrete - here coloured by recycled brick chippings for the construction of a Roman theatre. We had the vision of blooming gardens growing in these recycled soils amidst the ruins.

Towards the blast furnace, the sintering place is framed by a catwalk, leading to the "rail harp" on the upper level of the railway park.

From the high level walk, leading across the bunkers with a length of three hundred meters, the sintering place can be seen on one side, with the blast furnace visible on the other.

More importantly, the catwalk gives views down into the gardens.

On this picture you see Ailanthus altissima - "trees of heaven" - on the sintering place, growing also in recycled demolition rubbish. 


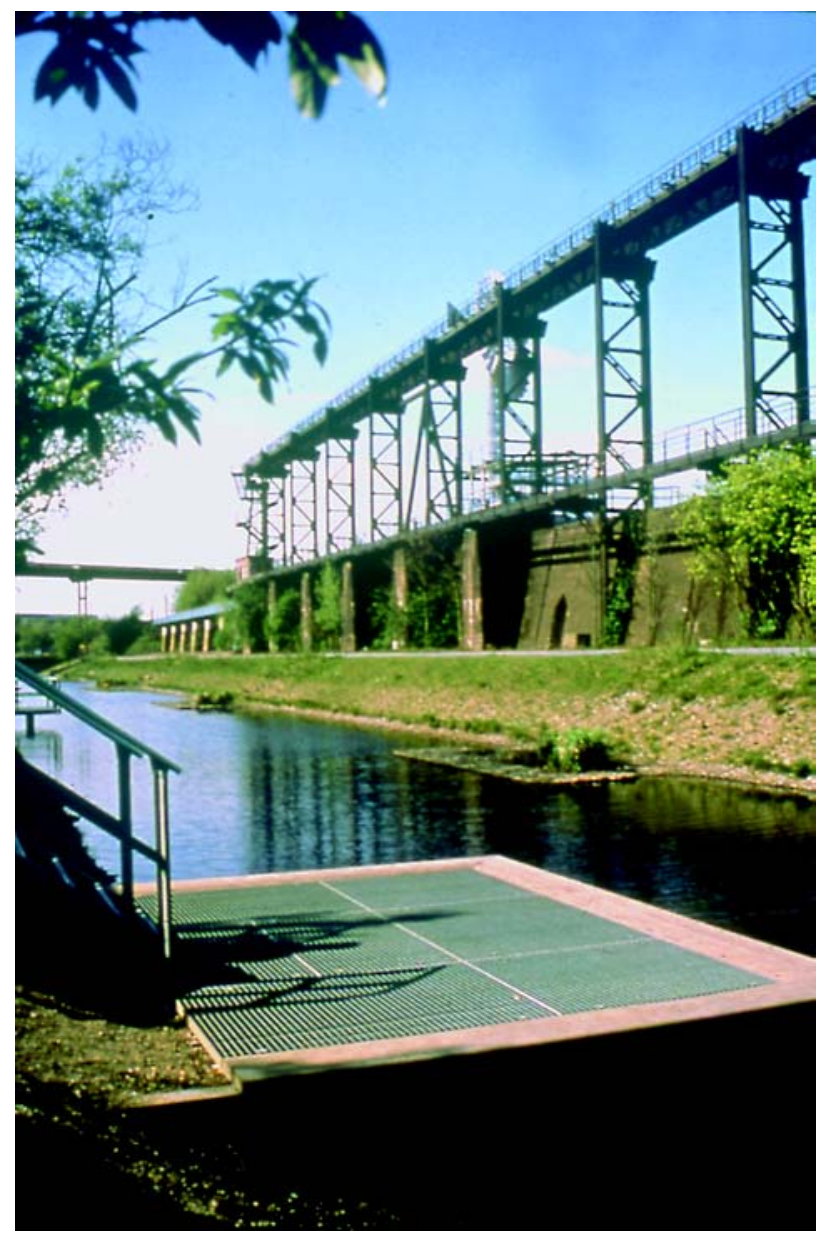

Figura 7 - The new channel, now filled with clear water Fonte: Christa Panick

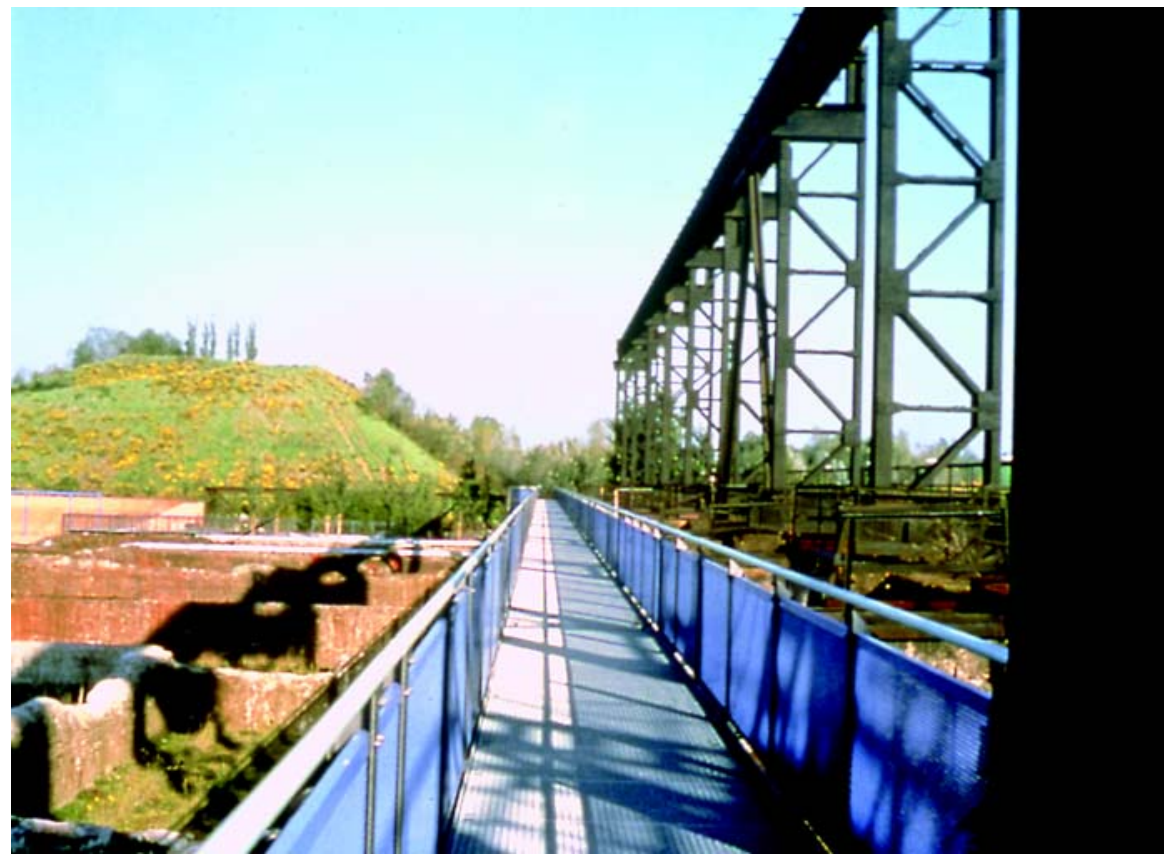

Figura 8 - The catwalk framing crossing the gardens within the former bunkers of the sintering plant and framing the 'Sintering Place' Fonte: Christa Panick 
Figura 9 - Three gardens within the former are bunkers of the sintering plant Fonte: Michael Latz

Figura 10 - Three gardens within the former are bunkers of the sintering plant Fonte: Christa Panick
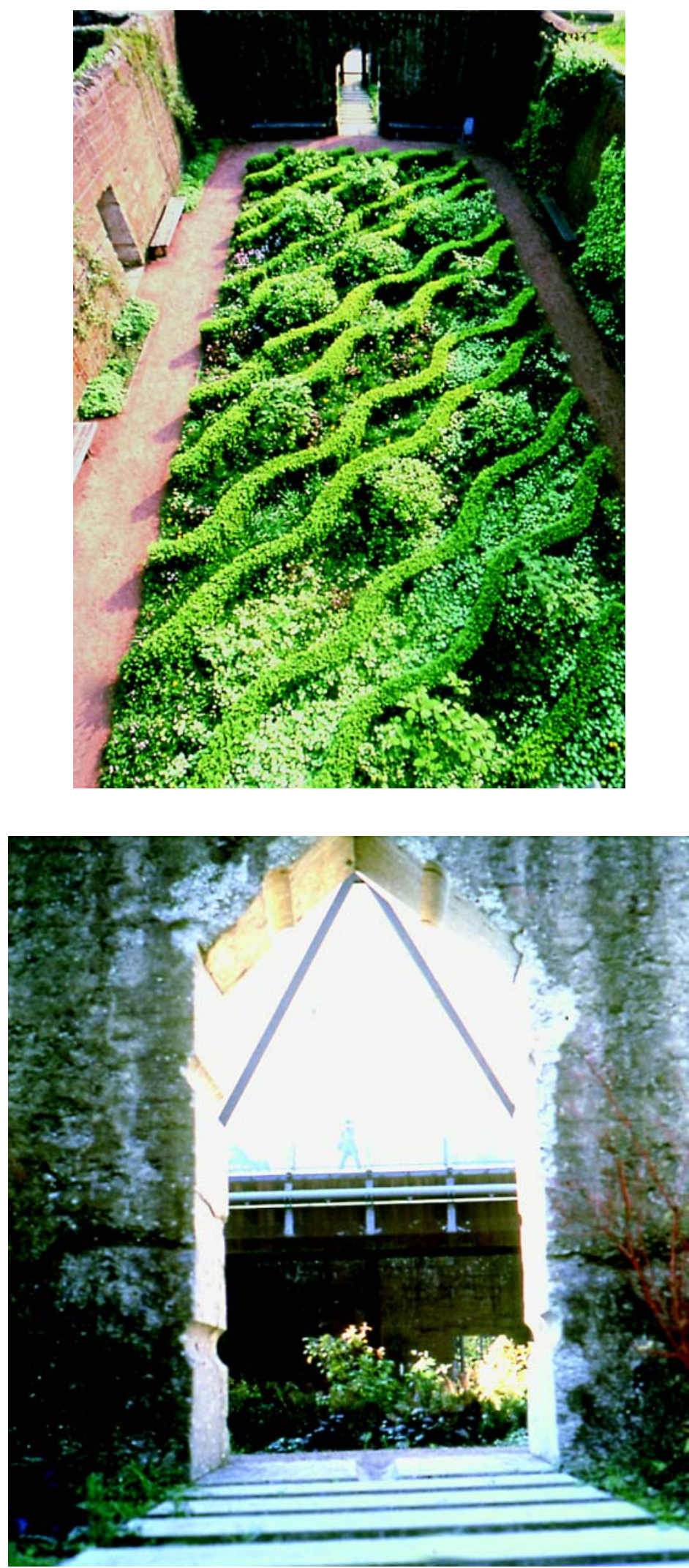
Essential parts of the catwalk are constructed with recycled material.

A simple construction, welded on site, lies on the restored piles of the former over-head railway.

As with the theatre, the catwalk uses bring colours, to signal, that these parts can be used, in contrast to untouched grey and rusty construction, which remain visibly "off limit".

Passing over these zones, you can watch the slowly growing bunker gardens, built at various heights and depths within the bunker site.

To get into the bunkers, we had to cut openings into the massive walls.

Where there were once heaped-up ore and coal deposits, there are now flourishing gardens of great variety, which, and that is rather seldom, can also be viewed as pictures from the catwalk.

Down here for example a garden, built with vegetation material from the rail harp: birch wood, overgrown by ferns and climbers in the meantime.

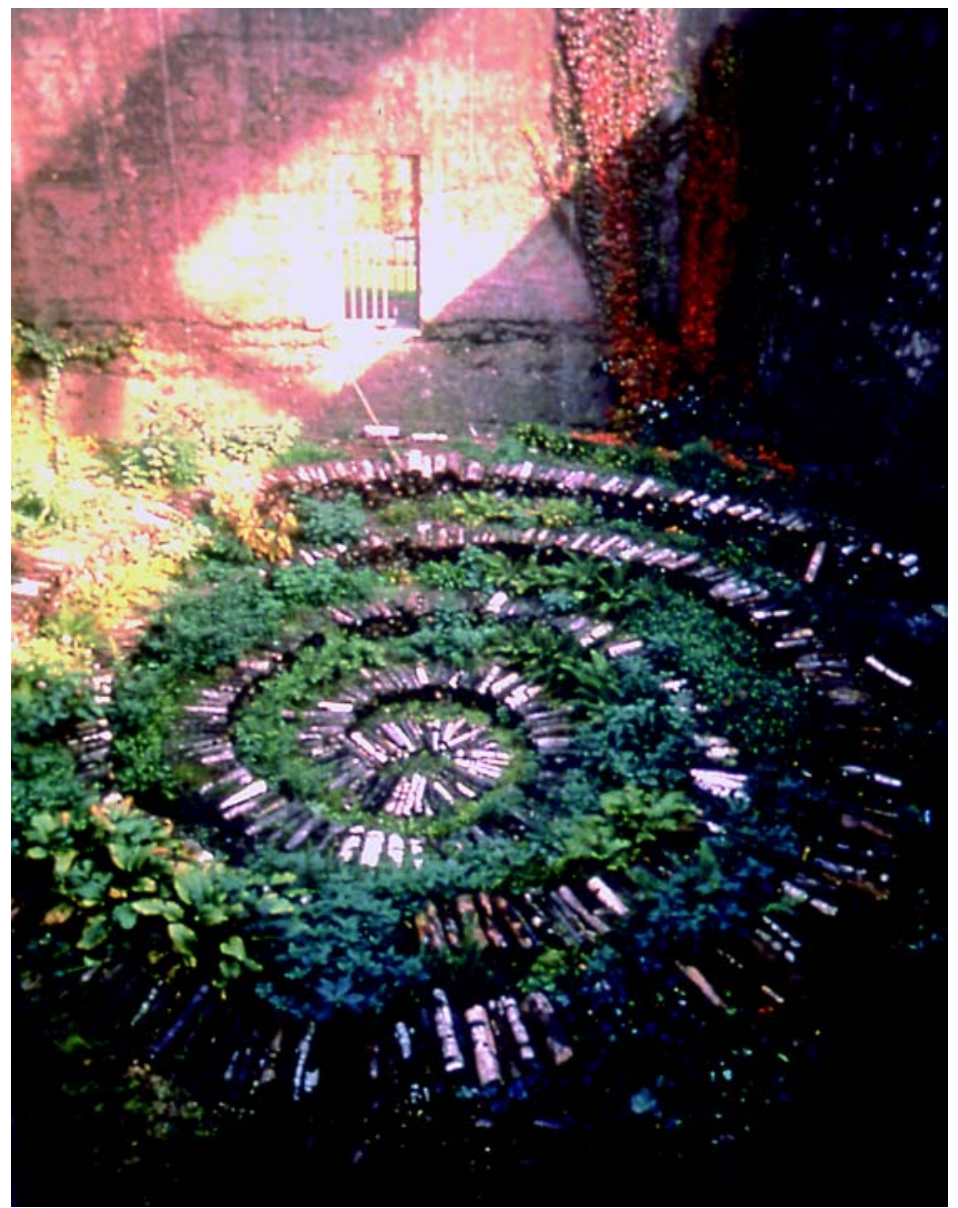

Figura 11 - Three gardens within the former are bunkers of the sintering plant Fonte: Christa Panick 


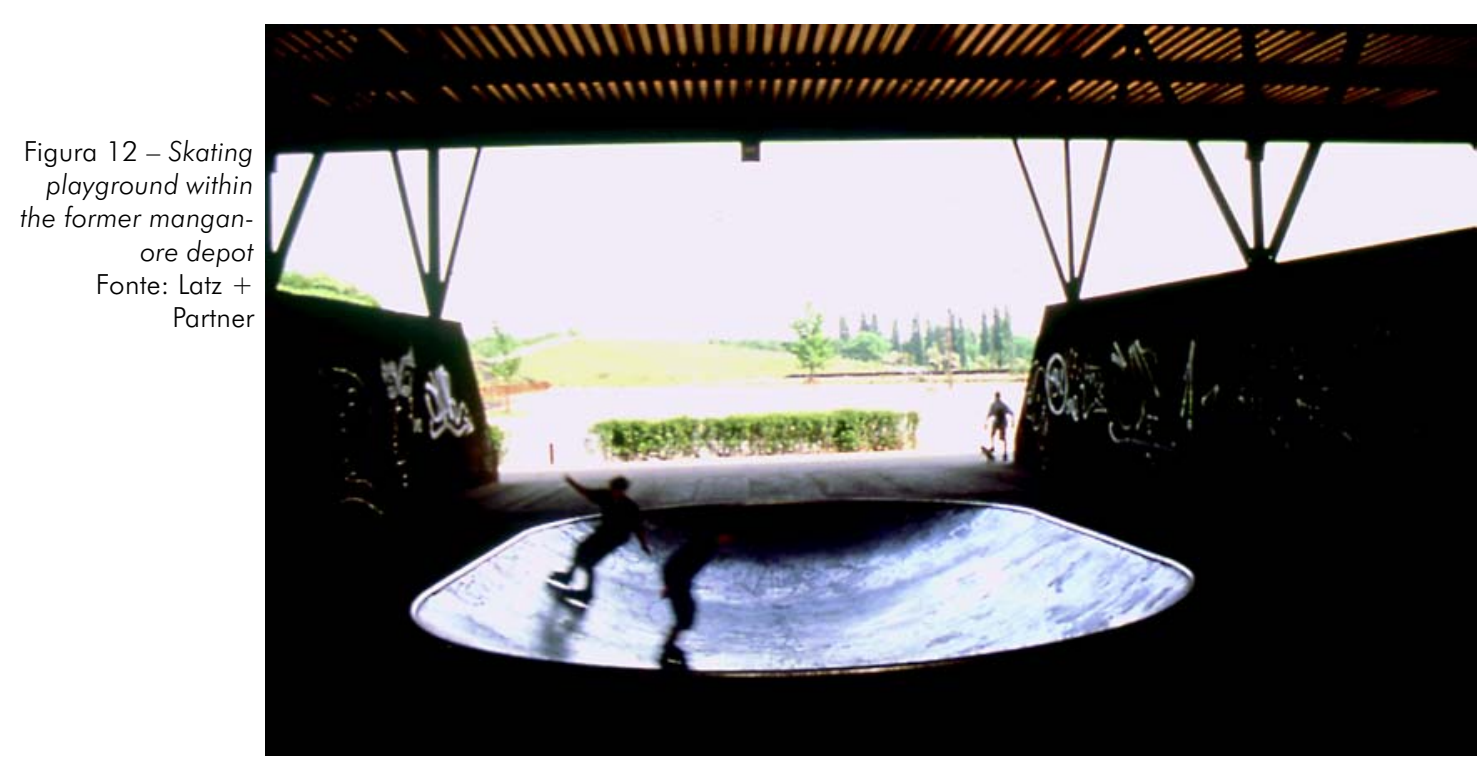

Formerly filled with ore, coal, lime and ashes, the walls enclose now sealed historical pollution, excavated materials, water or gardens.

In time, the greenery will dominate over the technical constructions, which fascinated in the beginning.

The end of the International Building Exhibition does not mean the end of building activities in the landscape park. Just now we are starting with important projects in two other bunker plants.

One is a playing ground for the youth in the bunkers of the former manganese ore depot - just being under construction.

Figura 13 - Water Playground beneath the windmill Fonte: Latz + Partner

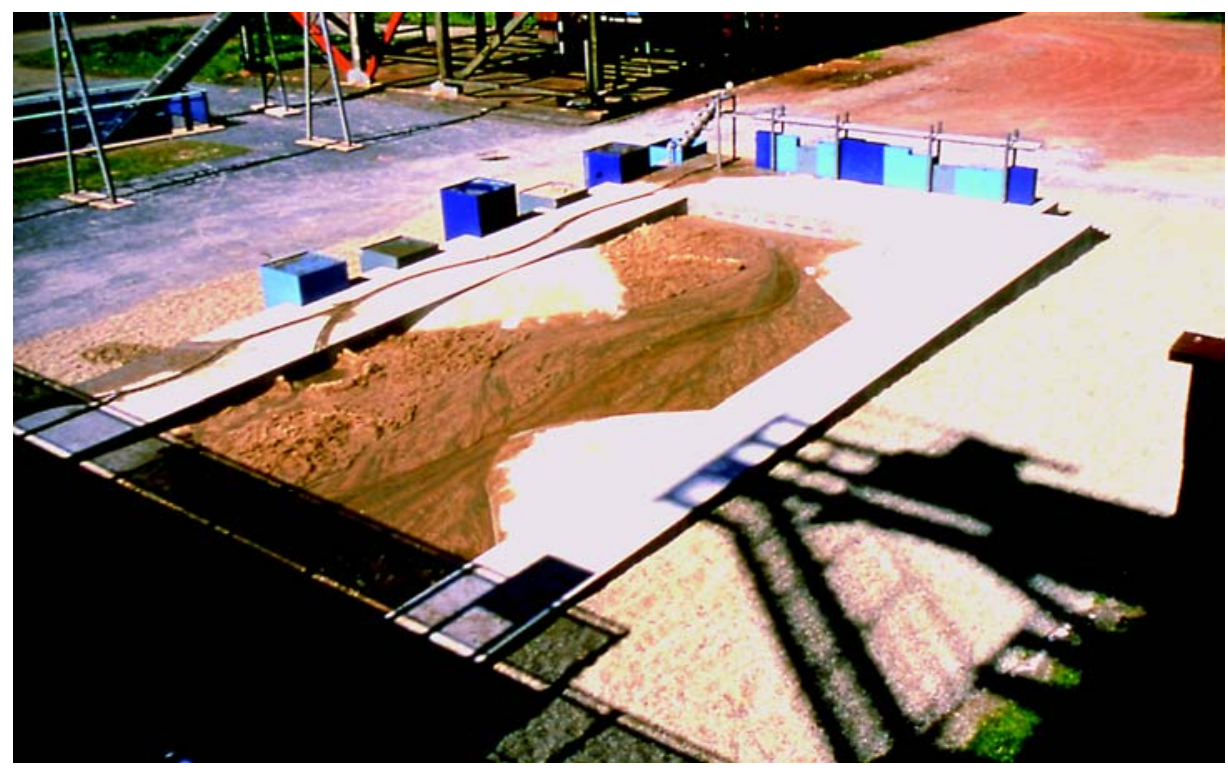


A place for sports and playing activities or just for sheltered stay...

Heavy walls made of steel will be covered with a light bar-ion construction, the whole ensemble completed with colours and light.

I tried out new ideas for a water playground on the beach, where the water was washing manifold forms into the sand...

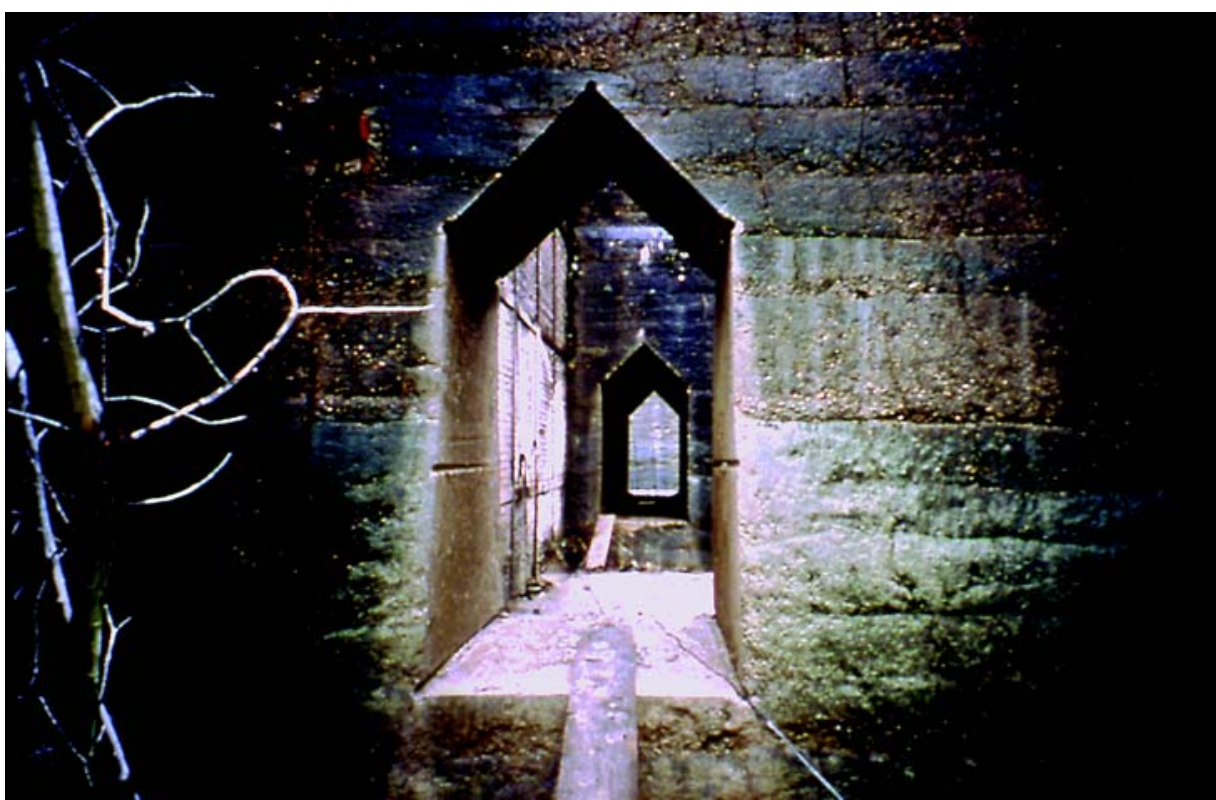

Figura 14 - Doors cut into the massive walls of the former are bunkers of the blast furnace which will be transformed by artistic interventions

Fonte: W. Riehl

Now, just below the windmill and below the concrete constructions, water and child's play will create natural forms of erosion in the sand.

Another actual project is the big ore bunker gallery.

The first idea was to make gardens in these mysterious tunnels.

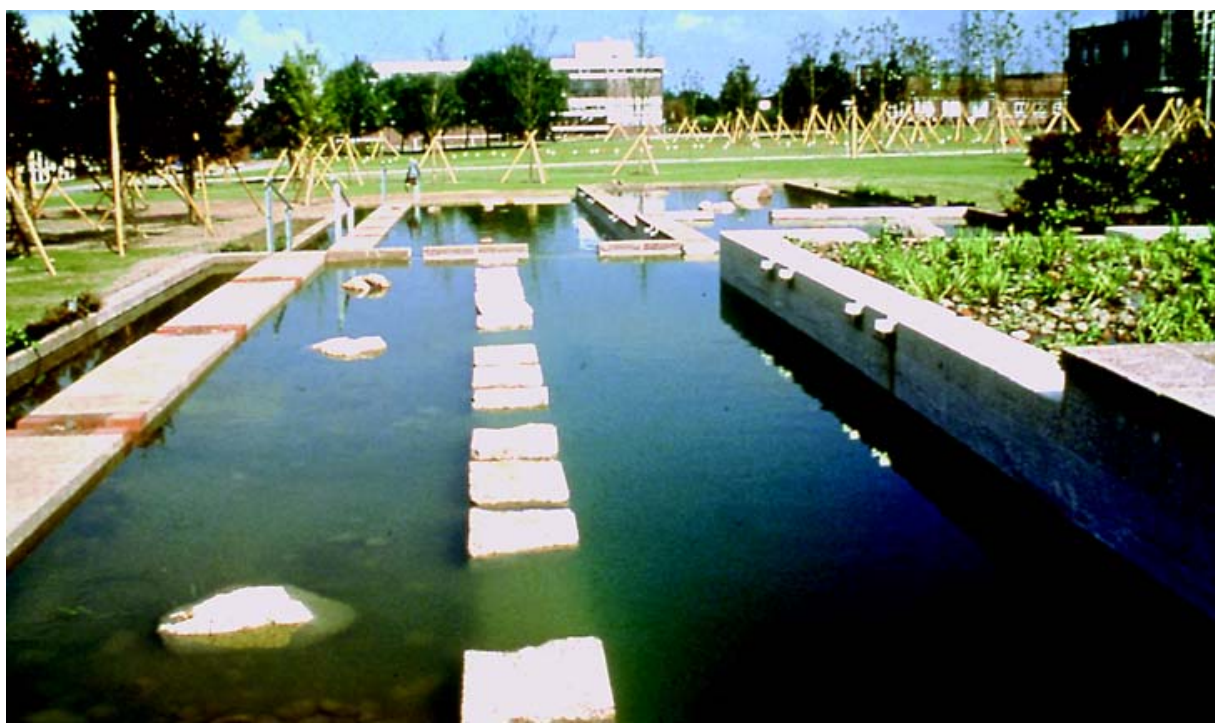

Figura 15 - Water bassin

Fonte: Latz + Partner 
The second approach led to a joint venture with the Lehmbruck Museum in Duisburg - a famous sculpture museum of contemporary art.

We started with a detailed survey of the structures with mountaineering methods.

Paths, footbridges and tunnels will connect the labyrinthine complex, and lead to artificial gardens with differentiated microclimates, with sound effects and various artistic interventions.

The first project will be created by the composer Humpert: a "sound roof" covering the future concrete labyrinth.

Pit Kroke will install his artwork of steel together with the music of Gerhard Stäbler.

So - bit by bit - there is growing another history, another understanding of the contaminated site and of the garden art.

The tasks of dealing with rum down industrial areas and open cast mines require a new method, that accepts their physical qualities, also their destroyed nature and topography.

This vision should not be one of "re-cultivation", for this approach negates the qualities, that they currently possess, and destroys them for a second time.

The vision for a new landscape should seek its justification exactly within the existing forms of demolition and exhaustion...

... as here at the border between Luxembourg and France, where the wild ore mining and industrial plants are to be transformed into a touristic region.

More than fifty percent (50\%) of this landscape have been dug up by excavators and penetrate by tunnels during the last hundred years.

The surface of this old agricultural land has totally changed. An area of two hundred fifty (250) square kilometers is showing forms, you can usually only find in the deserts.

These rocks are extremely acid, with a differentiated vegetation, rich in flowers and herbs and millions of orchids in springtime, that are already fascinating the nature conservation leagues.

Within such an area in Esch-sur-Alzette we were asked to design a park located in a forest. We suggested the local administration, rather to use these ore mining formations, to develop forms of recreation for a park, for a natural park of the "Re Rocks".

Remains of buildings and infrastructure can be made usable - in an area of picturesque charm with a steppe-like vegetation on the fragile formations of open cast mining. 


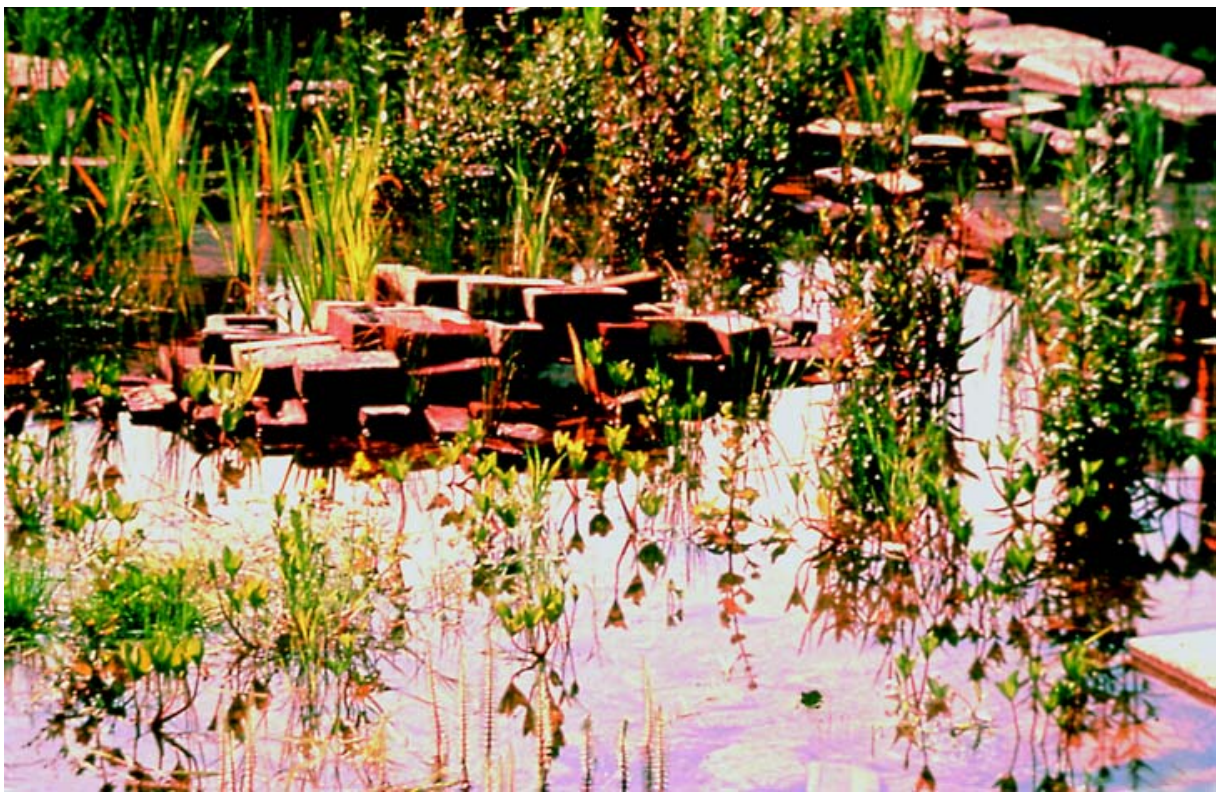

Figura 16 -

Recycled material in the flat bassin Fonte: Latz +

Partner

With another project I would like to show is a further contribution in the context of industrial history: a work we have done together with lan Hamilton Finlay for the Shell Research and Technology Center in Thornton.

122 In the middle of oil tanks and refineries art and landscape should complement each other to a small Arcadia, and new landscapes should build up on the remains of historic buildings, bearing visibly the traces of the past.

You see on the left picture the axis of the site with the old laboratory that was demolished and on the right the new wide and green gravel lawns and the old walls filled with water.

... a system of shallow water terraces and deep basins in the place of the old cable cellar.

Trees are situated in a new space, above the maze of the tubes and pipes of a highly complicated research site.

Dark pines and light pear trees and also the aquatics are growing in the recycled material of the demolished buildings.

The water is already clear, and the castle of the insects, of the dragonflies, is alive.

I would like to come to the end with a thesis: we landscape architects do not change the abandoned industrial sites. Instead, these sites are changing the way of thinking and the philosophy of our profession fundamentally. 